\title{
Pengenalan Pakan Blok Berbasiskan Dekanter Sawit Sebagai Pakan Ternak Ruminansia Di Desa Kota Baru, Kecamatan Geragai Kabupaten Tanjung Jabung Timur
}

\author{
M. Afdal*, Teja Kaswari, Saitul Fakhri, Heni Suryani \\ Fakultas Peternakan, Universitas Jambi, Indonesia \\ Penulis Koresponden m.afdal@unja.ac.id
}

\begin{abstract}
ABSTRAK
Tujuan dari kegiatan pengabdian kepada masyarakat ini adalah pemanfaatan dan pengenalan Dekanter Sawit (DS) kepada masyarakat peternak di desa Kotabaru. Pelaksanaan kegiatan ini adalah dengan memperkenalkan DS kepada anggota Kelompok Tani. Metoda yang dipergunakan adalah dengan survey pendahuluan terhadap potensi dan pemanfaatan DS di desa Kotabaru. Berdasarkan hasil survey pendahulaun ini maka diadakan sosialisai penggunaan DS sebagai pakan alternatif bagi ternak dengan program penyuluhan dan dilanjutkan dengan demonstrasi. Pada tahap awal ini diperkenalkan tata cara pembuatan pakan blok berbasiskan DS sebagai pakan alternatif untuk ternak ruminansia. Kesompulan dari program ini kelompok tani Suka Maju dapat menerima inovasi ini dengan memanfaatkan DS sebagai pakan alternatif ternak sapi dan sudah diadakan pelatihan pembuatan pakan blok berbasiskan DS
\end{abstract}

\section{PENDAHULUAN}

Berdasarkan program Pengabdian kepada Masyarakat pada tahun 2019, Kelompok Tani (Kelompok tani) Suka Maju yang berada di Desa Kota Baru, Kec. Geragai, Kab. Tanjung Jabung Timur merupakan sebuah Kelompok tani yang kemajuannya sangat dinamis sekali. Kelompok tani ini selalu mendapat bantuan rutin dari pada PT Petrocina berupa sapi bali. Kelompok tani ini juga sudah mempunyai Koperasi dengan nama Koperasi Suka Maju yang beranggotakan dari petani peternak yang berasal dari desa Kota Baru. Kebanyakan warga desa Kota Baru merupakan petani karet, kelapa sawit, disamping sebagai peternak dan pedagang. Pekerjaan sebagai peternak adalah sebagai usaha sampingan dari petani karet dan kelapa sawit.

Kelompok tani Sumber Jaya juga terdapat di desa Kota Baru. Kelompok tani ini merupakan Kelompok tani binaan dari Dinas Pertanian, Peternakan, Perikanan dan Kehutanan Kota Jambi. Kelompok tani ini memelihara sapi jenis Simanthal, Peranakan Ongole dan Brangus. Kelompok tani ini telah mendapat bantuan bergulir berupa 13 ekor sapi jantan dan 13 ekor sapi indukan pada tahun 2008. Peternak disini memelihara ternak kambing indukan sebanyak 150 ekor dan 30 ekor pejantan. Kalau populasi ternak kambing melebihi jumlah tersebut maka dilakukan penjualan.

Perkebunan kelapa sawit merupakan salah satu tanaman yang banyak diusahakan oleh petani di kedua Kelompok tani ini, disamping itu perkebunan swasta juga mengusahakan perkebunan kelapa sawit sehingga di daerah ini telah hadir dua pabrik pengolahan produk kelapa sawit baik dalam bentuk minyak mentah ataupun minyak inti sawit sebagai produk utamanya. Disamping produk utama ini, biasanya juga dihasilkan dekanter sawit (DS) yang merupakan salah satu produk sampingan/limbah dari pabrik pengolahan minyak sawit ini.Dari dua pabrik pengolahan minyak sawit ini diperkirakan akan menghasilkan limbah berupa dekanter sawit (DS) sebanyak 42 ton perpabrik perhari sesuai dengan laporan Utomo et al (2004). Sampai saat ini DS belum dimanfaatkan kecuali baru digunakan sebagai pupuk organik dan sebahagian sebagai sumber pakan ternak. Chavalvarid et al (2006) merekomandasikan penggunaan DS sebagai pakan ternak. Beberapa penelitian telah dilakukan untuk memanfaatkan DS sebagai pakan ternak, baik yang diberikan secara lansung maupun yang dicampurkan ke dalam ransum ternak (Afdal et al 2012; Utomo, 2001; Pimpa et al 2009).

Berdasarkan informasi diatas maka perlu pengenalan teknologi pemanfaatan DS sebagai pakan ternak. Dalam hal ini DS dapat diolah menjadi salah satu bahan pembuatan pakan blok untuk ternak 
sapi ataupun kambing. Pembuatan pakan blok dengan salah satu bahan dasar DS sangat memungkinkan karena ketersediaannya yang melimpah di Desa ini.Pengenalan teknologi pembuatan pakan blok dapat mempertahan daya simpan dari DS dan diharapkan dapat memperbaiki mutu pakan yang berakibat terhadap peningkatan produksi ternak sapi maupun kambing.

Prioritas dalam program pengabdian ini adalah melakukan sosialisasi pembuatan pakan blok dengan bahan dasar DS. Hal ini dilakukan dengan mengadakan pelatihan pembuatan pakan blok berbsasi DS.

\section{METODE PELAKSANAAN}

Program pengabdian ini telah dilaksanakan di Kelompok tani Suka Maju dan Sumber Jaya di desa Kota Baru Kecamatan Geragai Kabupaten Tanjung Jabung Timur. Peserta dari program ini merupakan partisipasi aktif dari seluruh anggota kelompok tani dan keluarga tani. Program pelaksanakan program pengabdian ini meliputi penyuluhan dan demonstrasi plot.

\section{Penyuluhan Tentang Pemanfaatan Dekanter Sawit Sebagai Pakan Alternatif}

Penyuluhan adalah salah satu program dalam pelaksanaan pengabdian kepada masyarakat. Sebelum acara penyuluhan juga telah diadakan survey pendahuluan terhadap kondisi dilapangan dan kesiapan para anggota kelompok tani. Survey ini telah dilakukan jauh hari tepatnya tanggal 23 April 2020 setelah itu Tim dengan ketua Kelompok Tani selalu berkomunikasi secara pribadi ataupun bersama-sama mengenai rencana pelaksanaan penyuluhan dengan para anggota Kelompok Tani, tepatnya tanggal 20 Juni 2020 dan tanggal 19 Juli 2020. Penyuluhan tentang pemanfatan dan kegunaan DS sebagai salah satu sumber bahan pakan alternatif bagi ternak ruminansia seperti ternak kambing dan sapi, telah dilaksanakan pada tanggal 2 Agustus 2020. Tujuan dari program ini adalah memberikan pengertian kepada peternak tentang arti penting, kegunaan, pemanfaatan serta teknologi pengolahan DS sebagai salah satu sumber pakan ternak alternatif.

Pelaksanaan penyuluhan ini akan dilaksanakan di Saung Kelompok Tani di Desa Kota Baru yang akan diikuti oleh semua peternak yang berasal dari anggota Kelompok Tani Suka Maju dan Sumber Jaya dan peternak lain yang diluar anggota Kelompok Tani. Dalam penyuluhan ini akan melibatkan tenaga Penyuluh Pertanian Lapangan ataupun pihak terkait seperti kepala Desa, Kepala Dusun dan ibu ibu PKK di Desa Kota Baru. Materi dalam penyuluhan ini meliputi pemanfaatan DS sebagai salah satu sumber bahan pakan alternatif, metoda pengawetannya serta pengolahannya dan pemberian DS dalam ransum ternak.

\section{Praktek Pembuatan Pakan Blok}

Setelah pelaksanaan penyuluhan maka dilaksanakan demonstrasi cara pembuatan pakan blok dengan bahan DS sebagai campuran dasar. Pelaksanaan demonstrasi pembuatan pakan blok ini juga melibatkan semua peternak. Bahan dasar pembuatan pakan blok ini merupakan campuran dari DS dengan bahan pakan lain seperti molases, dedak padi, jagung giling dan semen untuk perekan. Metoda pembuatan pakan blok ini mengacu kepata prosedur Nurwahidah et al (2015). Setelah selesai pembuatan pakan blok ini maka pakan blok ini akan dicobakan lansung diberikan kepada ternak kambing atau pun ternak sapi yang ada di peternakan sapi ataupun kambing di desa Kota Baru.

\section{HASIL DAN PEMBAHASAN}

Penyuluhan terhadap anggota Kelompok Tani Suka Maju dilaksanakan pada tanggal 2 Agustus 2020 (Foto kegiatan penyuluhan terlampir). Penyuluhan diikuti oleh 23 peternak anggota kelompok tani Suka maju. Materi dalam penyuluhan ini meliputi pengenalan DS, ketersediaan DS di Desa Kota Baru, manfaat DS sebagai bahan pakan alternatif untuk ternak ruminansia dan pengenalan pakan blok yang berbasiskan DS. Foto kegiatan dapat dilihat pada Gambar 1. 

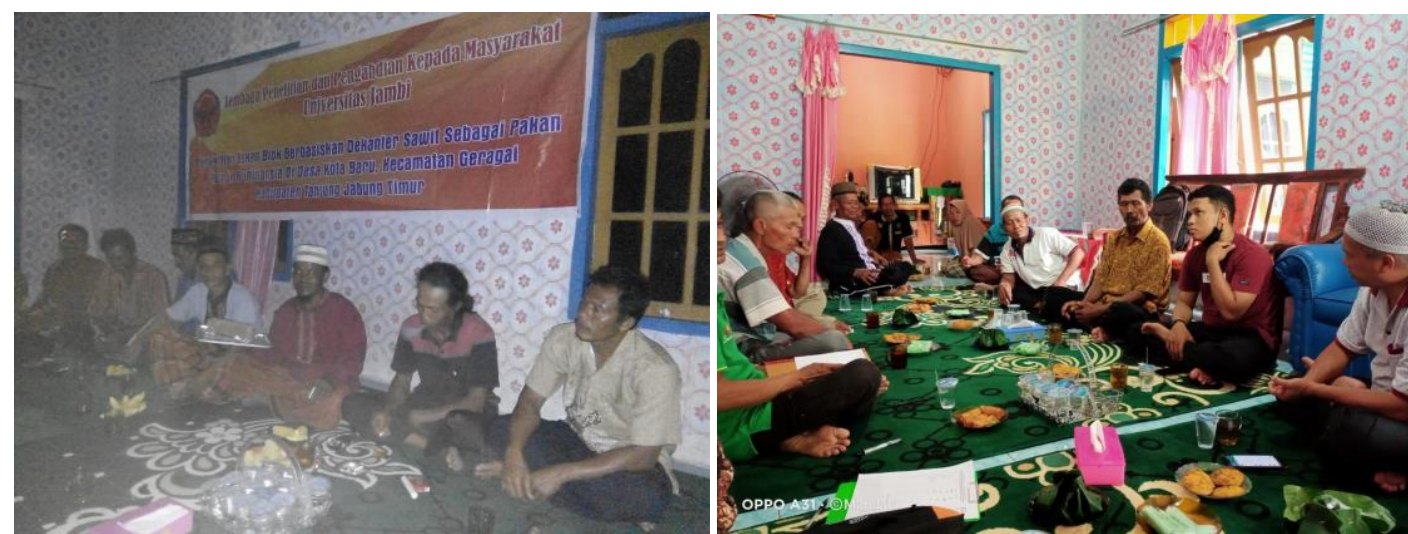

Gambar 1. Foto kegiatan penyuluhan pengenalan pakan blok kepada kelompot Tani Suka Maju

\section{Demostrasi pembuatan pakan blok}

Pengenalan teknologi pemanfaatan DS dalam pembuatan pakan blok merupakan program dari pengabdian kepada masyarakat ini. Dalam hal ini peternakan dilatih dengan demostrasi pembuatan pakan blok dengan bahan dasar utama DS dan ditambahkan dengan jagung giling, dedak padi, tepung tapioka, molases dan semen sebagai sumber mineral. Pembuatan pakan blok ini berdasarkan pengeringan dengan matahari (petunjuk pembuatan blok terlampir). Foto kegiatan dapat dilihat pada Gambar 2, 3, 4 dan 5.
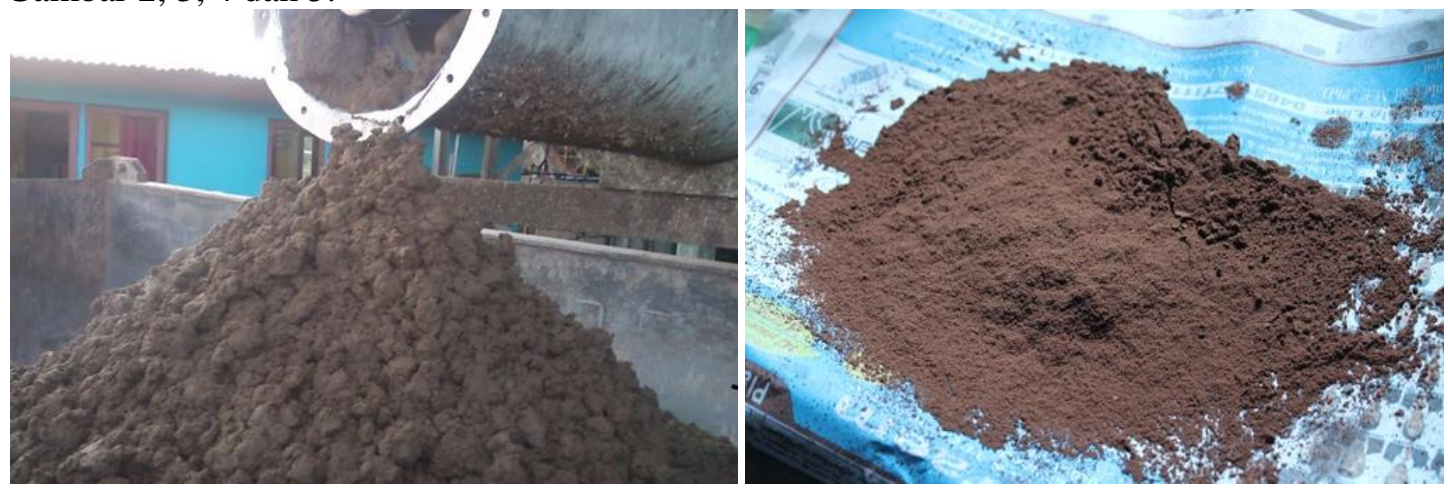

Gambar 2. Dekanter sawit segar dari pubrik dan tepung dekanter sawit

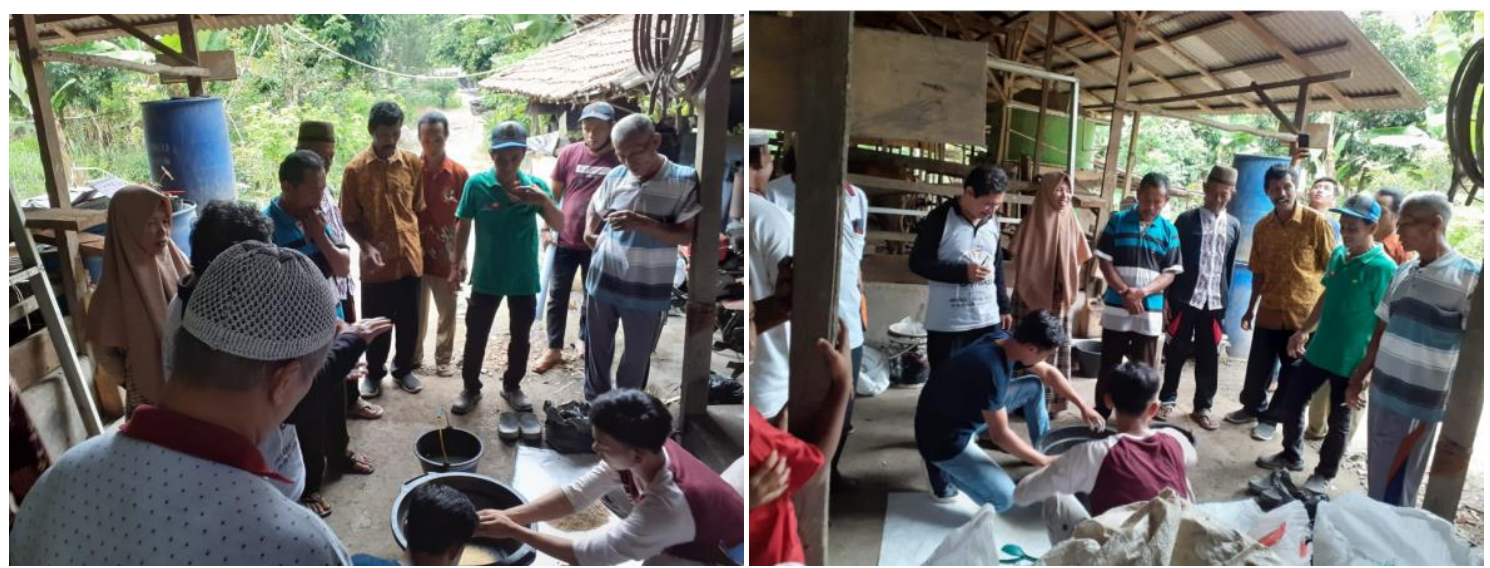

Gambar 3. Demonstrasi pembuatan Blok Dekanter Sawit oleh Mahasiswa 


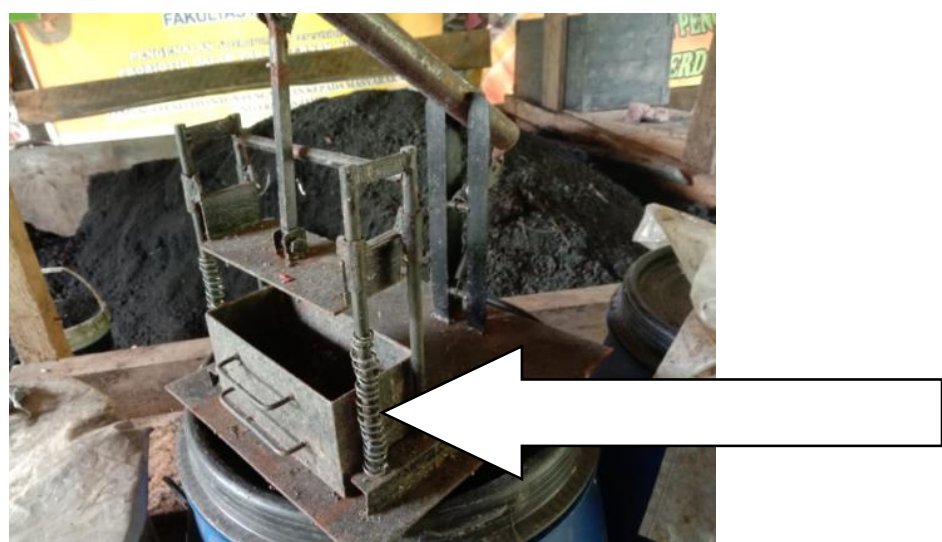

a. Alat pembuat pakan blok

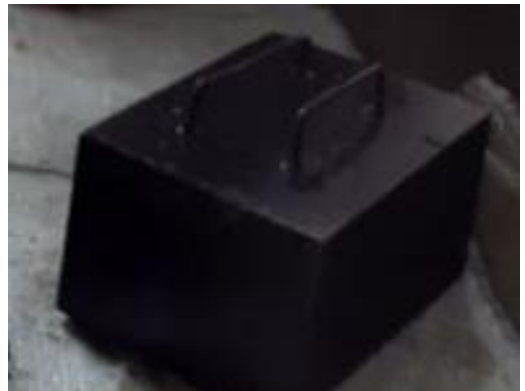

b. Blok pencetak pakan

Gambar 4. Alat pencetak pakan blok
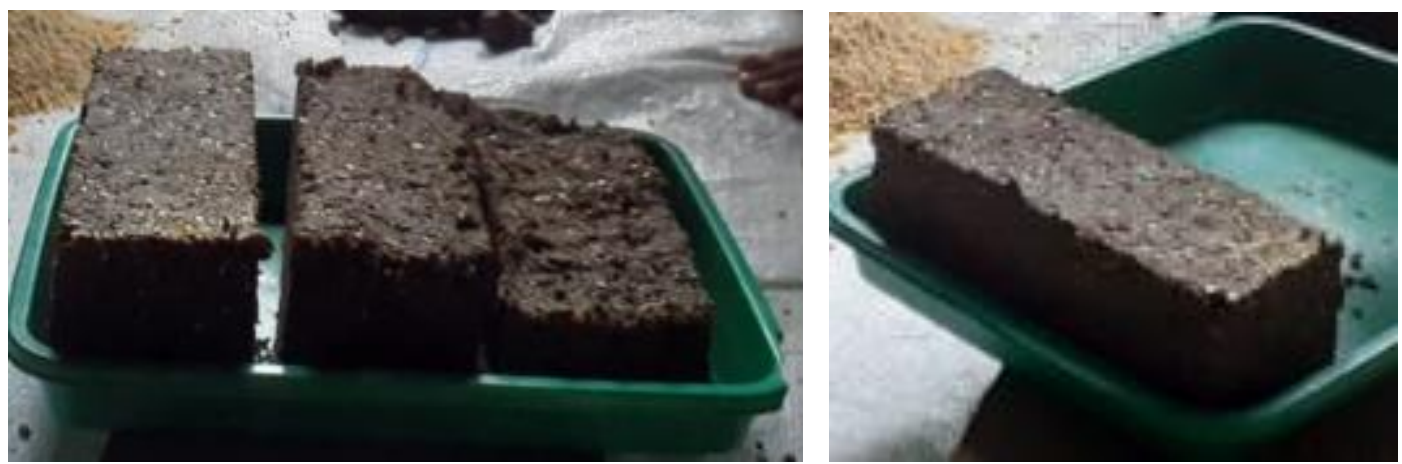

Gambar 5. Pakan blok yang siap dipanaskan atau dijemur

Berdasarkan hasil yang telah dilaksanakan berupa penyuluhan dan demostrasi pembuatan pakan blok berbasiskan kepada DS, terlihat bahwa keingin-tahuan petani peternak terhadap DS yang tersedia di daerahnya. Sebahagian peternak sudah menggunakan DS sebagai bahan pakan untuk ternaknya walaupun masih ada yang belum menggunakan DS sebagai pakan ternak karena belum adanya pengetahuan tentang DS. Harapan kedepannya dengan adanya sosialisasi DS ini diharapkan akan membuka peluang kedepannya untuk pengembangan usaha pakan blok ini karena ini sangat didukung dengan potensi ketersediaan DS di desa Kotabaru ini.

\section{KESIMPULAN DAN SARAN}

Pengenalan dan pembuatan sampel pakan blok berbasikan DS telah dilaksanakan terhadap anggota kelompok tani Suka maju. Hasil dari program pengabdian ini diharapkan dapat memanfaatkan DS sebagai bahan pakan alternatif untuk ternak ruminansia.

Hasil dari program Pengabdian kepada Masyarakat ini dapat ditindak lanjuti ke;pada taraf pensosialisasian pakan blok berbasis DS kepada seluruh masyarakat peternak di desa Kota Baru Kecamatan Geragai. Lebih lanjut akan dicobakan pengkomersialisasikan pakan blok ini, dalam hal ini perlu pembinaan dari pihak inkobator bisnis Universitas jambi maupun dari pihak Pemerintah Daerah Kabupaten Tanjung Jabung Timur dalam jajaran Dinas Peternakan dan atau Dinas Perindustrian dan Perdagangan. 


\section{DAFTAR PUSTAKA}

Afdal, M., Azhar Kasim; A. R. Alimon and N Abdullah. (2012). Evaluation of the Palatability of Palm Oil Decanter Meal Preserved with Ground Cinnamon Stick (Cinnamomum burmanniiy) on goat. Journal of Animal and Veterinary Advances 11 (20): 3749-3754

Pimpa, O., Reungsuwan, S., \& Pimpa, B. (2009). Utilization of decanter cake from oil palm mill for concentrate and urea molasses multinutrient block production for beef cattle. 2nd International Conference on Sustainable Animal Agriculture for Developing Countries Kuala Lumpur Malaysia 8th-11th November 2009. Kuala Lumpur: Institute of Bioscience, Universiti Putra Malaysia. (pp. 150-151)

Utomo, B. N. (2001). Potential of oil palm solid waste as local feed resources for cattle in Central Kalimantan, Indonesia. . The Netherland.: MSc Thesis. Wageningen University

Utomo, B. N., Widjaja, E., Hartono, A., Sintha, E., \& Adriansyah. (2004). A final report of technology exibition: The utilisation of solid sawit by-product as broiler feed. Palangkaraya Indonesia: BPTP Central Kalimantan 